EPRA International Journal of Economic and Business Review-Peer Reviewed Journal

Volume - 9, Issue - 11, November 2021 | e-ISSN: 2347 - 9671| p- ISSN: 2349 - 0187

\title{
ROLE OF TALENT DEVELOPMENT IN ENHANCING INNOVATIONS IN INFORMATION TECHNOLOGY SECTOR: AN INVESTIGATIVE STUDY
}

\author{
Dr. V. Tulasi Das ${ }^{1}$, Mrs. R.V.Naga Sailaja ${ }^{2}$ \\ ${ }^{1}$ Chairman, BoS (PG) in HRM, Dept. of HRM, Acharya Nagarjuna University, Guntur- 522 510, A.P. \\ ${ }^{2}$ Research Scholar, Dept. of HRM, Acharya Nagarjuna University, Guntur-522 510, A.P.
}

\begin{abstract}
DOI No: 10.36713/epra9021

Article DOI: https://doi.org/10.36713/epra9021

The ability of entrepreneurs to produce new products is fundamental, because the organisational environment changes rapidly. Changes in socio-economic systems, changes in the expectations and needs and desires of customers, are challenges faced by organisations through new products or services as well. Innovations created by companies are the key to competitive advantage that determines the success of an organisation (Kuratko, 2015; Urbancova, 2012). Talent development is the driver of innovation. Therefore, current research focuses on to study the employee perception talent development impact on innovation.
\end{abstract}

KEY WORDS: Strategy, Structure, Climate, Culture, Socio-Economic System.

\section{INTRODUCTION}

Innovation is the driver of the company's success in the long run, especially in dynamic market (Baker, 2005). Innovation will increase the added value of a product and must be able to make different products so that consumers are more interested in buying these products than competing products (Jaworski, 1993). Talent development is the driver of innovation.

\section{TALENT DEVELOPMENT APPROACHES FOR INNOVATION}

Empirical evidence suggests a mixture of approaches in organisations. A CIPD (2011) study found that many organisations have adopted an exclusive approach that focuses on developing senior managers. There is a lot of focus on high potentials, future stars, future leaders and high-fliers. However, while the McKinsey Consulting Group initially advocated an exclusive approach to talent development, they now advocate a more inclusive approach that targets development for not just "A players" but also "B players" (Ernst \& Young, 2010). However, relatively few organisations adopt inclusive approaches. A study reported in Public Personnel Management (Reilly, 2008) suggested that inclusive approaches to talent development are more likely to be found in public sector organisations. Bersin (2010) calls this inclusive approach a form of talent segmentation but with recognition that all groups of employees have a contribution to make to the organisation. Such an approach is consistent with an innovation perspective on talent (Christensen et al., 2010). This suggests that all employees should be regarded as great talent given their potential to generate creative ideas. 


\section{REVIEW OF LITERATURE}

Organizational innovation refers to the creation or adoption of an idea or behaviour hence successful implementation of them within the organization (Amabile, 1998). The goal of innovation is to create business value by developing worthwhile ideas into a customer-centric marketable reality (J. Lee et. al., 2010).Innovation, in addition to developing firm's capabilities enables it to correspond with environmental changes, and thus is necessary for an organization to have a long-lasting life (J.H. Collins, 2008; J. Rhee, 2009; A.R. Ma'atoofi, 2010) . Human Resources practices have been found to play an important role in stimulating organizational innovation by enhancing the creativity of individual employees. Often innovation is seen as the result of collaboration and team work. However, innovation is largely in the hands of individuals: individuals play a vital role in all innovations because they are the holders and processors of ideas (A.A.R. Veenendaal, 2015). Whereas humans are the foundations of organizational transformations, talented human resource maintenance should be paid to reach the acceptable organizational level of development. The talent management is a process that traverses direction for evolution from its emersion. Talent management includes strategy and thinking based on attracting resources, selecting, training, developing, marinating, promoting and transferring workers within the organization (M.F. Nosh Abadi et. al., 2013).

Juan A. Marin-Garcia et. al., 2021 said that innovation is a recent topic in academic literature and research nowadays, and many authors coincide in the stating that innovation is neither easy to implement nor to maintain in companies, whether dealing with the incremental or the radical type of innovation (Marín-García et al., 2010). Researchers have focused on the identification of the essential competencies to promote and enhance innovation in companies. They have classified the types of innovation according to three categories which include the levels of innovation achieved in each of them, and they have discovered a serious gap in the literature concerning innovation.

Osaka, 2021 created Ono Starts Innovation Talent Development Program in his company Ono Pharmaceutical Co., Ltd. It has started a temporary assignment program to venture companies, "V2V (Voyage to Venture)" and an in-house business contest, "HOPE" as from October 2021 in the Ono Innovation Platform (OIP), which was established as a foundation for accelerating the challenges of their staff. They have been working to promote our "strengthening corporate infrastructure", in order to improve organisation's corporate value and achieve sustainable growth. One of the important themes in the "strengthening corporate infrastructure" is the development of "human resources (talent)" that will be the source of further innovation creation, and the establishment of a corporate culture that supports the challenges of the staff.

Jori Hamilton (12/01/2021) found that one of the main errors a business can make is becoming stagnant. In the digital age, the world frequently changes. That often means that to retain the competitive edge, one must innovate. Talent development can introduce employees to new skills and new ways of thinking about the challenges they face - and overcoming them. As such, it is an essential element in building a sustainable culture of innovation within the company.

Sumita Datta et. al., 2021 suggested that empirical investigations on innovation should be directed toward explorations of the contributions of a Talent Development Climate to the knowledge management processes, at cross-functional and cross-managerial levels, with specific reference to group level effects of the construct.

\section{OBJECTIVES OF THE STUDY}

- To study literature and find the factors influencing talent development and innovations in information technology sector.

- To examine the talent development impact on innovation in select information technology organisation in Mindspace IT Park, Hyderabad.

- To put forth certain suggestions based on the findings.

\section{SAMPLE AND DATA COLLECTION}

A quantitative approach was followed in this exploratory study. The participants selected for this study consisted of select information technology organisation in Mindspace IT park, Hyderabad employees. 650 questionnaires were distributed among the select companies. Convenience sampling technique was deployed in sample selection. The respondents were solicited to complete thetalent development and innovation questionnaire. The resultant response rate of useable questionnaires was $98.5 \%$ (640). 
TALENT DEVELOPMENT IMPACT ON INNOVATION

Table-1: Regression Model of Individual Innovative Personality and Talent Development among employees of select IT companies

\begin{tabular}{|l|c|c|c|c|}
\hline \multicolumn{5}{|c|}{ Model Summary } \\
\hline Model & $\mathrm{R}$ & $\mathrm{R}$ Square & Adjusted R Square & Std. Error of the Estimate \\
\hline 1 & $.513^{\mathrm{a}}$ & .264 & .260 & 1.16113 \\
\hline \multicolumn{2}{|l}{ a. Predictors: (Constant), TDF, TDAS, TDP } \\
\hline
\end{tabular}

(Source: Primary Data)

From the above table it is observed that the corelation coefficient $\mathrm{R}=.513$ it indicates the relation between Talent Development and Individual Innovative Personality Parameter of Innovation is constructive and both alter in the identical path. The coefficient of variance $\mathrm{R}^{2}$ shows that $26.4 \%$ of the deviation in the dependant factor (Individual Innovative Personality) is explained by the independent factor (Talent Development). The adjusted $\mathrm{R}^{2}$ mentioned in the above table shows the generalisability of the model. It enables generalising the result obtained from the select IT company employees to the universe. It is observed that the value of adjusted $\mathrm{R}^{2}=.260$ is close to the value of $\mathrm{R}^{2}=.264$. If the adjusted $\mathrm{R}^{2}$ is expelled from the $\mathrm{R}^{2}$ the value will be $(.264$ $.260=.004)$. This sum of decrease means that if the sample universe participates in the research and the model has been fitted then, there will be $0.4 \%$ less difference in the outcome.

\begin{tabular}{|l|l|r|r|r|r|c|}
\hline \multicolumn{7}{|c|}{ ANOVA $^{\text {a }}$} \\
\hline \multicolumn{2}{|l|}{ Model } & Sum of Squares & df & Mean Square & F & Sig. \\
\hline \multirow{3}{*}{1} & Regression & 306.886 & 3 & 102.295 & 75.874 & $.000^{\mathrm{b}}$ \\
\cline { 2 - 7 } & Residual & 857.471 & 636 & 1.348 & & \\
\cline { 2 - 7 } & Total & 1164.357 & 639 & & & \\
\hline
\end{tabular}

(Source: Primary Data)

The Analysis of Variance (ANOVA) allows researchers to test the null hypothesis statistically. The above table shows the result of ANOVA test, where the $\mathrm{F}$ ratio $=75.874$ and the $\mathrm{P}$ - value $<0.05$, this outcome indicates that there is less than $5 \%$ change that an F ratio of this value would be occur only coincidentally. Since the P-value is lesser than the significant level (0.05), the null hypothesis is rejected and alternative hypothesis is accepted signifying that Talent Development affects IT employees Individual Innovative Personality.

\begin{tabular}{|c|c|c|c|c|c|c|}
\hline \multicolumn{7}{|c|}{ Coefficients $^{\mathrm{a}}$} \\
\hline \multirow{2}{*}{\multicolumn{2}{|c|}{ Model }} & \multicolumn{2}{|c|}{ Unstandardized Coefficients } & \multirow{2}{*}{$\begin{array}{c}\text { Standardized } \\
\text { Coefficients } \\
\text { Beta }\end{array}$} & \multirow[t]{2}{*}{$\mathrm{t}$} & \multirow[t]{2}{*}{ Sig. } \\
\hline & & B & Std. Error & & & \\
\hline \multirow[t]{4}{*}{1} & (Constant) & 1.217 & .135 & & 9.002 & .000 \\
\hline & TDAS & .280 & .092 & .2 & 3.031 & .003 \\
\hline & TDP & .050 & .114 & .0 & .436 & .663 \\
\hline & TDF & .202 & .064 & .2 & 3.146 & .002 \\
\hline
\end{tabular}

(Source: Primary Data)

The result in the above coefficient table revealed that Talent Development affects IT employees Individual Innovative Personality.

Table-2: Regression Model of Individual Innovative Motivation and Talent Development among employees of select IT companies

\begin{tabular}{|l|l|c|c|c|}
\hline \multicolumn{5}{|c|}{ Model Summary } \\
\hline Model & $\mathrm{R}$ & $\mathrm{R}$ Square & Adjusted R Square & Std. Error of the Estimate \\
\hline 1 & $.488^{\mathrm{a}}$ & .238 & .235 & 1.20687 \\
\hline \multicolumn{2}{|l}{ a. Predictors: (Constant), TDF, TDAS, TDP } \\
\hline
\end{tabular}

(Source: Primary Data)

From the above table it is observed that the corelation coefficient $\mathrm{R}=.488$ it indicates the relation between Talent Development and Individual Innovative Motivation Parameter of Innovation is constructive and both alter in the identical path. The coefficient of variance $\mathrm{R}^{2}$ shows that $23.8 \%$ of the deviation in the dependant 
factor (Individual Innovative Motivation) is explained by the independent factor (Talent Development). The adjusted $\mathrm{R}^{2}$ mentioned in the above table shows the generalisability of the model. It enables generalising the result obtained from the select IT company employees to the universe. It is observed that the value of adjusted $\mathrm{R}^{2}=.235$ is close to the value of $\mathrm{R}^{2}=.238$. If the adjusted $\mathrm{R}^{2}$ is expelled from the $\mathrm{R}^{2}$ the value will be $(.238$ $.235=.003)$. This sum of decrease means that if the sample universe participates in the research and the model has been fitted then, there will be $0.3 \%$ less difference in the outcome.

\begin{tabular}{|c|c|c|c|c|c|c|}
\hline \multicolumn{7}{|c|}{ ANOVA $^{a}$} \\
\hline \multicolumn{2}{|c|}{ Model } & Sum of Squares & $\mathrm{df}$ & Mean Square & $\mathrm{F}$ & Sig. \\
\hline \multirow[t]{3}{*}{1} & Regression & 289.623 & 3 & 96.541 & 66.282 & $.000^{\mathrm{b}}$ \\
\hline & Residual & 926.352 & 636 & 1.457 & & \\
\hline & Total & 1215.975 & 639 & & & \\
\hline \multicolumn{7}{|c|}{ a. Dependent Variable: Motivation } \\
\hline \multicolumn{7}{|c|}{ b. Predictors: (Constant), TDF, TDAS, TDP } \\
\hline
\end{tabular}

(Source: Primary Data)

The Analysis of Variance (ANOVA) allows researchers to test the null hypothesis statistically. The above table shows the result of ANOVA test, where the F ratio $=66.282$ and the P-value $<0.05$, this outcome indicates that there is less than $5 \%$ change that an $\mathrm{F}$ ratio of this value would be occur only coincidentally. Since the P-value is lesser than the significant level (0.05), the null hypothesis is rejected and alternative hypothesis is accepted signifying that Talent Development affects IT employees Individual Innovative Motivation.

\begin{tabular}{|c|c|c|c|c|c|c|}
\hline \multicolumn{7}{|c|}{ Coefficients $^{\mathrm{a}}$} \\
\hline \multirow{2}{*}{\multicolumn{2}{|c|}{ Model }} & \multicolumn{2}{|c|}{ Unstandardized Coefficients } & \multirow{2}{*}{$\frac{\text { Standardized Coefficients }}{\text { Beta }}$} & \multirow[t]{2}{*}{$\mathrm{t}$} & \multirow[t]{2}{*}{ Sig. } \\
\hline & & $\mathrm{B}$ & Std. Error & & & \\
\hline \multirow[t]{4}{*}{1} & (Constant) & 1.229 & .141 & & 8.742 & .000 \\
\hline & TDAS & .354 & .096 & .348 & 3.680 & .000 \\
\hline & TDP & -.064 & .119 & -.063 & -.540 & .589 \\
\hline & TDF & .227 & .067 & .232 & 3.391 & .001 \\
\hline
\end{tabular}

(Source: Primary Data)

The result in the above coefficient table revealed that Talent Development affects IT employees Individual Innovative Motivation.

Table-3: Regression Model of Individual Innovative Cognition and Talent Development among employees of select IT companies

\begin{tabular}{|l|c|c|r|r|}
\hline \multicolumn{5}{|c|}{ Model Summary } \\
\hline Model & $\mathrm{R}$ & R Square & Adjusted R Square & Std. Error of the Estimate \\
\hline 1 & $.502^{\mathrm{a}}$ & .252 & .249 & 1.17172 \\
\hline a. Predictors: (Constant), TDF, TDAS, TDP \\
\hline
\end{tabular}

(Source: Primary Data)

From the above table it is observed that the corelation coefficient $\mathrm{R}=.502$ it indicates the relation between Talent Development and Individual Innovative Cognition Parameter of Innovation is constructive and both alter in the identical path. The coefficient of variance $\mathrm{R}^{2}$ shows that $25.2 \%$ of the deviation in the dependant factor (Individual Innovative Cognition) is explained by the independent factor (Talent Development). The adjusted $\mathrm{R}^{2}$ mentioned in the above table shows the generalisability of the model. It enables generalising the result obtained from the select IT company employees to the universe. It is observed that the value of adjusted $\mathrm{R}^{2}=.249$ is close to the value of $\mathrm{R}^{2}=.252$. If the adjusted $\mathrm{R}^{2}$ is expelled from the $\mathrm{R}^{2}$ the value will be $(.252-.249=.003)$. This sum of decrease means that if the sample universe participates in the research and the model has been fitted then, there will be $0.3 \%$ less difference in the outcome.

\begin{tabular}{|c|c|c|c|c|c|c|}
\hline \multicolumn{7}{|c|}{ ANOVA $^{a}$} \\
\hline \multicolumn{2}{|c|}{ Model } & Sum of Squares & df & Mean Square & $\mathrm{F}$ & Sig. \\
\hline \multirow[t]{3}{*}{1} & Regression & 294.372 & 3 & 98.124 & 71.470 & $.000^{\mathrm{b}}$ \\
\hline & Residual & 873.187 & 636 & 1.373 & & \\
\hline & Total & 1167.559 & 639 & & & \\
\hline \multicolumn{7}{|c|}{ a. Dependent Variable: Cognition } \\
\hline \multicolumn{7}{|c|}{ b. Predictors: (Constant), TDF, TDAS, TDP } \\
\hline
\end{tabular}

(Source: Primary Data) 
The Analysis of Variance (ANOVA) allows researchers to test the null hypothesis statistically. The above table shows the result of ANOVA test, where the F ratio $=71.470$ and the P-value $<0.05$, this outcome indicates that there is less than $5 \%$ change that an $\mathrm{F}$ ratio of this value would be occur only coincidentally. Since the P-value is lesser than the significant level (0.05), the null hypothesis is rejected and alternative hypothesis is accepted signifying that Talent Development affects IT employees Individual Innovative Cognition.

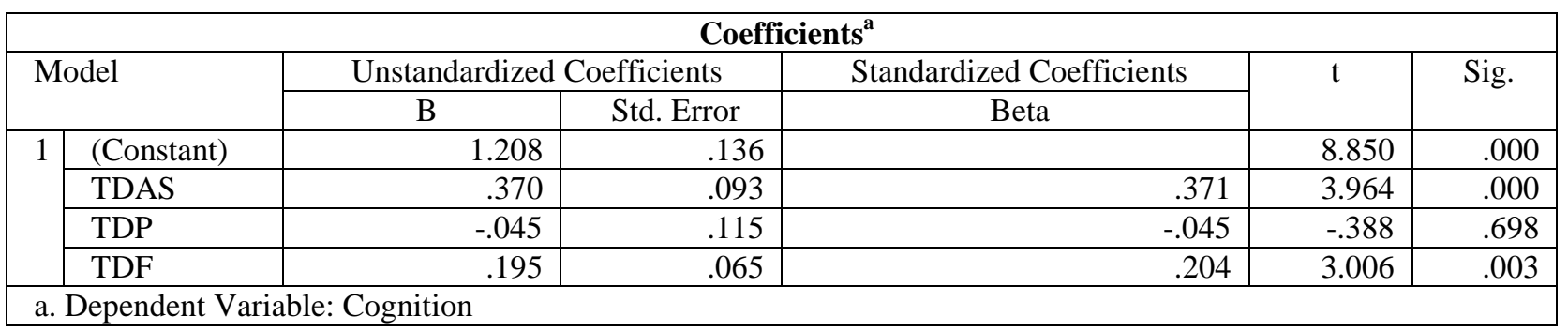

(Source: Primary Data)

The result in the above coefficient table revealed that Talent Development affects IT employees Individual Innovative Cognition.

Table-4: Regression Model of Group Structure and Talent Development among employees of select IT companies

\begin{tabular}{|c|c|c|c|c|}
\hline \multicolumn{5}{|c|}{ Model Summary } \\
\hline Model & $\mathrm{R}$ & R Square & Adjusted R Square & Std. Error of the Estimate \\
\hline 1 & $.487^{\mathrm{a}}$ & .237 & .233 & 1.21390 \\
\hline
\end{tabular}

From the above table it is observed that the corelation coefficient $\mathrm{R}=.487$ it indicates the relation between Talent Development and Group Structure Parameter of Innovation is constructive and both alter in the identical path. The coefficient of variance $\mathrm{R}^{2}$ shows that $23.7 \%$ of the deviation in the dependant factor (Group Structure) is explained by the independent factor (Talent Development). The adjusted $\mathrm{R}^{2}$ mentioned in the above table shows the generalisability of the model. It enables generalising the result obtained from the select IT company employees to the universe. It is observed that the value of adjusted $\mathrm{R}^{2}=.233$ is close to the value of $\mathrm{R}^{2}=.237$. If the adjusted $\mathrm{R}^{2}$ is expelled from the $\mathrm{R}^{2}$ the value will be $(.237-.233=.004)$. This sum of decrease means that if the sample universe participates in the research and the model has been fitted then, there will be $0.4 \%$ less difference in the outcome.

\begin{tabular}{|c|c|c|c|c|c|c|}
\hline \multicolumn{7}{|c|}{ ANOVA $^{\text {a }}$} \\
\hline \multicolumn{2}{|c|}{ Model } & Sum of Squares & df & Mean Square & $\mathrm{F}$ & Sig. \\
\hline \multirow[t]{3}{*}{1} & Regression & 290.916 & 3 & 96.972 & 65.809 & $.000^{\mathrm{b}}$ \\
\hline & Residual & 937.177 & 636 & 1.474 & & \\
\hline & Total & 1228.094 & 639 & & & \\
\hline \multicolumn{7}{|c|}{ a. Dependent Variable: GStructure } \\
\hline \multicolumn{7}{|c|}{ b. Predictors: (Constant), TDF, TDAS, TDP } \\
\hline
\end{tabular}

(Source: Primary Data)

The Analysis of Variance (ANOVA) allows researchers to test the null hypothesis statistically. The above table shows the result of ANOVA test, where the F ratio $=65.809$ and the P-value $<0.05$, this outcome indicates that there is less than $5 \%$ change that an F ratio of this value would be occur only coincidentally. Since the P-value is lesser than the significant level (0.05), the null hypothesis is rejected and alternative hypothesis is accepted signifying that Talent Development affects IT employees Group Structure.

\begin{tabular}{|c|c|c|c|c|c|c|}
\hline \multicolumn{7}{|c|}{ Coefficients $^{\mathrm{a}}$} \\
\hline \multirow{2}{*}{\multicolumn{2}{|c|}{ Model }} & \multicolumn{2}{|c|}{ Unstandardized Coefficients } & \multirow{2}{*}{$\begin{array}{c}\text { Standardized Coefficients } \\
\text { Beta }\end{array}$} & \multirow[t]{2}{*}{$\mathrm{t}$} & \multirow[t]{2}{*}{ Sig. } \\
\hline & & $\mathrm{B}$ & Std. Error & & & \\
\hline \multirow[t]{4}{*}{1} & (Constant) & 1.219 & .141 & & 8.625 & .000 \\
\hline & TDAS & .302 & .097 & .296 & 3.126 & .002 \\
\hline & TDP & .041 & .119 & .041 & .347 & .729 \\
\hline & TDF & .175 & .067 & .178 & 2.594 & .010 \\
\hline
\end{tabular}

(Source: Primary Data) 
The result in the above coefficient table revealed that Talent Development affects IT employees Group Structure.

Table-5: Regression Model of Group Climate and Talent Development among employees of select IT companies

\begin{tabular}{|l|c|c|r|r|}
\hline \multicolumn{5}{|c|}{ Model Summary } \\
\hline Model & R & R Square & Adjusted R Square & Std. Error of the Estimate \\
\hline 1 & $.530^{\mathrm{a}}$ & .281 & .277 & 1.15070 \\
\hline a. Predictors: (Constant), TDF, TDAS, TDP
\end{tabular}

(Source: Primary Data)

From the above table it is observed that the corelation coefficient $\mathrm{R}=.530$ it indicates the relation between Talent Development and Group Climate Parameter of Innovation is constructive and both alter in the identical path. The coefficient of variance $\mathrm{R}^{2}$ shows that $28.1 \%$ of the deviation in the dependant factor (Group Climate) is explained by the independent factor (Talent Development). The adjusted $\mathrm{R}^{2}$ mentioned in the above table shows the generalisability of the model. It enables generalising the result obtained from the select IT company employees to the universe. It is observed that the value of adjusted $\mathrm{R}^{2}=.277$ is close to the value of $\mathrm{R}^{2}=.281$. If the adjusted $\mathrm{R}^{2}$ is expelled from the $\mathrm{R}^{2}$ the value will be $(.281-.277=.004)$. This sum of decrease means that if the sample universe participates in the research and the model has been fitted then, there will be $0.4 \%$ less difference in the outcome.

\begin{tabular}{|c|c|c|c|c|c|c|}
\hline \multicolumn{7}{|c|}{ ANOVA $^{a}$} \\
\hline \multicolumn{2}{|c|}{ Model } & Sum of Squares & df & Mean Square & $\mathrm{F}$ & Sig. \\
\hline \multirow[t]{3}{*}{1} & Regression & 328.797 & 3 & 109.599 & 82.771 & $.000^{\mathrm{b}}$ \\
\hline & Residual & 842.139 & 636 & 1.324 & & \\
\hline & Total & 1170.936 & 639 & & & \\
\hline \multicolumn{7}{|c|}{ a. Dependent Variable: Climate } \\
\hline \multicolumn{7}{|c|}{ b. Predictors: (Constant), TDF, TDAS, TDP } \\
\hline
\end{tabular}

The Analysis of Variance (ANOVA) allows researchers to test the null hypothesis statistically. The above table shows the result of ANOVA test, where the F ratio $=82.771$ and the P-value $<0.05$, this outcome indicates that there is less than $5 \%$ change that an F ratio of this value would be occur only coincidentally. Since the P-value is lesser than the significant level (0.05), the null hypothesis is rejected and alternative hypothesis is accepted signifying that Talent Development affects IT employees Group Climate.

\begin{tabular}{|c|c|c|c|c|c|c|}
\hline \multicolumn{7}{|c|}{ Coefficients $^{\mathrm{a}}$} \\
\hline \multirow{2}{*}{\multicolumn{2}{|c|}{ Model }} & \multicolumn{2}{|c|}{ Unstandardized Coefficients } & \multirow{2}{*}{$\begin{array}{r}\text { Standardized Coefficients } \\
\text { Beta }\end{array}$} & \multirow[t]{2}{*}{$\mathrm{t}$} & \multirow[t]{2}{*}{ Sig. } \\
\hline & & $\mathrm{B}$ & Std. Error & & & \\
\hline \multirow[t]{4}{*}{1} & (Constant) & 1.249 & .134 & & 9.317 & .000 \\
\hline & TDAS & .246 & .092 & .247 & 2.690 & .007 \\
\hline & TDP & .143 & .113 & .143 & 1.265 & .206 \\
\hline & TDF & .160 & .064 & .167 & 2.516 & .012 \\
\hline
\end{tabular}

a. Dependent Variable: Climate

(Source: Primary Data)

The result in the above coefficient table revealed that Talent Development affects IT employees Group Climate.

Table-6: Regression Model of Group Leadership and Talent Development among employees of select IT companies

\begin{tabular}{|l|l|c|c|r|}
\hline \multicolumn{5}{|c|}{ Model Summary } \\
\hline Model & $\mathrm{R}$ & R Square & Adjusted R Square & Std. Error of the Estimate \\
\hline 1 & $.511^{\mathrm{a}}$ & .261 & .258 & 1.16732 \\
\hline \multicolumn{7}{|l}{ a. Predictors: (Constant), TDF, TDAS, TDP } \\
\hline
\end{tabular}

(Source: Primary Data)

From the above table it is observed that the corelation coefficient $\mathrm{R}=.511$ it indicates the relation between Talent Development and Group Leadership Parameter of Innovation is constructive and both alter in the identical path. The coefficient of variance $\mathrm{R}^{2}$ shows that $26.1 \%$ of the deviation in the dependant factor (Group Leadership) is explained by the independent factor (Talent Development). The adjusted $\mathrm{R}^{2}$ mentioned in the 
above table shows the generalisability of the model. It enables generalising the result obtained from the select IT company employees to the universe. It is observed that the value of adjusted $R^{2}=.258$ is close to the value of $R^{2}$ $=.261$. If the adjusted $\mathrm{R}^{2}$ is expelled from the $\mathrm{R}^{2}$ the value will be $(.261-.258=.003)$. This sum of decrease means that if the sample universe participates in the research and the model has been fitted then, there will be $0.3 \%$ less difference in the outcome.

\begin{tabular}{|c|c|c|c|c|c|c|}
\hline \multicolumn{7}{|c|}{ ANOVA $^{\mathbf{a}}$} \\
\hline \multicolumn{2}{|c|}{ Model } & Sum of Squares & $\mathrm{df}$ & Mean Square & $\mathrm{F}$ & Sig. \\
\hline \multirow[t]{3}{*}{1} & Regression & 306.459 & 3 & 102.153 & 74.968 & $.000^{\mathrm{b}}$ \\
\hline & Residual & 866.631 & 636 & 1.363 & & \\
\hline & Total & 1173.090 & 639 & & & \\
\hline \multicolumn{7}{|c|}{ a. Dependent Variable: Leadership } \\
\hline \multicolumn{7}{|c|}{ b. Predictors: (Constant), TDF, TDAS, TDP } \\
\hline
\end{tabular}

(Source: Primary Data)

The Analysis of Variance (ANOVA) allows researchers to test the null hypothesis statistically. The above table shows the result of ANOVA test, where the F ratio $=74.968$ and the $\mathrm{P}$ - value $<0.05$, this outcome indicates that there is less than $5 \%$ change that an $\mathrm{F}$ ratio of this value would be occur only coincidentally. Since the P- value is lesser than the significant level (0.05), the null hypothesis is rejected and alternative hypothesis is accepted signifying that Talent Development affects IT employees Group Leadership.

\begin{tabular}{|c|c|c|c|c|c|c|}
\hline \multicolumn{7}{|c|}{ Coefficients $^{\mathbf{a}}$} \\
\hline \multirow{2}{*}{\multicolumn{2}{|c|}{ Model }} & \multicolumn{2}{|c|}{ Unstandardized Coefficients } & \multirow{2}{*}{$\begin{array}{c}\text { Standardized Coefficients } \\
\text { Beta }\end{array}$} & \multirow[t]{2}{*}{$\mathrm{t}$} & \multirow[t]{2}{*}{ Sig. } \\
\hline & & $\mathrm{B}$ & Std. Error & & & \\
\hline \multirow[t]{4}{*}{1} & (Constant) & 1.259 & .136 & & 9.262 & .000 \\
\hline & TDAS & .270 & .093 & .270 & 2.901 & .004 \\
\hline & TDP & .106 & .115 & .106 & .923 & .357 \\
\hline & TDF & .156 & .065 & .162 & 2.408 & .016 \\
\hline
\end{tabular}

The result in the above coefficient table revealed that Talent Development affects IT employees Group Leadership.

Table-7: Regression Model of Organisational Structure and Talent Development among employees of select IT companies

\begin{tabular}{|l|l|c|c|c|}
\hline \multicolumn{5}{|c|}{ Model Summary } \\
\hline Model & R & R Square & Adjusted R Square & Std. Error of the Estimate \\
\hline 1 & $.541^{\mathrm{a}}$ & .293 & .290 & 1.13139 \\
\hline \multicolumn{2}{|l|}{ a. Predictors: (Constant), TDF, TDAS, TDP } \\
\hline
\end{tabular}

(Source: Primary Data)

From the above table it is observed that the corelation coefficient $\mathrm{R}=.541$ it indicates the relation between Talent Development and Organisational Structure Parameter of Innovation is constructive and both alter in the identical path. The coefficient of variance $\mathrm{R}^{2}$ shows that $29.3 \%$ of the deviation in the dependant factor (Organisational Structure) is explained by the independent factor (Talent Development). The adjusted $\mathrm{R}^{2}$ mentioned in the above table shows the generalisability of the model. It enables generalising the result obtained from the select IT company employees to the universe. It is observed that the value of adjusted $\mathrm{R}^{2}=.290$ is close to the value of $\mathrm{R}^{2}=.293$. If the adjusted $\mathrm{R}^{2}$ is expelled from the $\mathrm{R}^{2}$ the value will be $(.293-.290=.003)$. This sum of decrease means that if the sample universe participates in the research and the model has been fitted then, there will be $0.3 \%$ less difference in the outcome.

\begin{tabular}{|c|c|c|c|c|c|c|}
\hline \multicolumn{7}{|c|}{ ANOVA $^{a}$} \\
\hline \multicolumn{2}{|c|}{ Model } & Sum of Squares & $\mathrm{df}$ & Mean Square & $\mathrm{F}$ & Sig. \\
\hline \multirow[t]{3}{*}{1} & Regression & 337.419 & 3 & 112.473 & 87.867 & $.000^{\mathrm{b}}$ \\
\hline & Residual & 814.108 & 636 & 1.280 & & \\
\hline & Total & 1151.527 & 639 & & & \\
\hline \multicolumn{7}{|c|}{ a. Dependent Variable: OStructure } \\
\hline \multicolumn{7}{|c|}{ b. Predictors: (Constant), TDF, TDAS, TDP } \\
\hline
\end{tabular}

(Source: Primary Data) 
The Analysis of Variance (ANOVA) allows researchers to test the null hypothesis statistically. The above table shows the result of ANOVA test, where the F ratio $=87.867$ and the P-value $<0.05$, this outcome indicates that there is less than $5 \%$ change that an $\mathrm{F}$ ratio of this value would be occur only coincidentally. Since the P-value is lesser than the significant level (0.05), the null hypothesis is rejected and alternative hypothesis is accepted signifying that Talent Development affects IT employees Organisational Structure.

\begin{tabular}{|c|c|c|c|c|c|c|}
\hline \multicolumn{7}{|c|}{ Coefficients $^{\mathrm{a}}$} \\
\hline \multirow{2}{*}{\multicolumn{2}{|c|}{ Model }} & \multicolumn{2}{|c|}{ Unstandardized Coefficients } & \multirow{2}{*}{$\begin{array}{c}\text { Standardized Coefficients } \\
\text { Beta }\end{array}$} & \multirow[t]{2}{*}{$\mathrm{t}$} & \multirow[t]{2}{*}{ Sig. } \\
\hline & & $\mathrm{B}$ & Std. Error & & & \\
\hline \multirow[t]{4}{*}{1} & (Constant) & 1.208 & .132 & & 9.169 & .000 \\
\hline & TDAS & .181 & .090 & .183 & 2.013 & .045 \\
\hline & TDP & .208 & .111 & .210 & 1.871 & .062 \\
\hline & TDF & .166 & .063 & .175 & 2.652 & .008 \\
\hline
\end{tabular}

(Source: Primary Data)

The result in the above coefficient table revealed that Talent Development affects IT employees Organisational Structure.

Table-8: Regression Model of Organisational Culture and Talent Development among employees of select IT companies

\begin{tabular}{|l|c|c|c|c|}
\hline \multicolumn{5}{|c|}{ Model Summary } \\
\hline Model & $\mathrm{R}$ & R Square & Adjusted R Square & Std. Error of the Estimate \\
\hline 1 & $.547^{\mathrm{a}}$ & .300 & .296 & 1.13115 \\
\hline \multicolumn{7}{|l|}{ a. Predictors: (Constant), TDF, TDAS, TDP } \\
\hline
\end{tabular}

(Source: Primary Data)

From the above table it is observed that the corelation coefficient $\mathrm{R}=.547$ it indicates the relation between Talent Development and Organisational Culture Parameter of Innovation is constructive and both alter in the identical path. The coefficient of variance $\mathrm{R}^{2}$ shows that $30.0 \%$ of the deviation in the dependant factor (Organisational Culture) is explained by the independent factor (Talent Development). The adjusted $\mathrm{R}^{2}$ mentioned in the above table shows the generalisability of the model. It enables generalising the result obtained from the select IT company employees to the universe. It is observed that the value of adjusted $\mathrm{R}^{2}=.296$ is close to the value of $\mathrm{R}^{2}=.300$. If the adjusted $\mathrm{R}^{2}$ is expelled from the $\mathrm{R}^{2}$ the value will be $(.300-.296=.004)$. This sum of decrease means that if the sample universe participates in the research and the model has been fitted then, there will be $0.4 \%$ less difference in the outcome.

\begin{tabular}{|c|c|c|c|c|c|c|}
\hline \multicolumn{7}{|c|}{ ANOVA $^{a}$} \\
\hline \multicolumn{2}{|c|}{ Model } & Sum of Squares & df & Mean Square & $\mathrm{F}$ & Sig. \\
\hline \multirow[t]{3}{*}{1} & Regression & 348.318 & 3 & 116.106 & 90.743 & $.000^{\mathrm{b}}$ \\
\hline & Residual & 813.768 & 636 & 1.280 & & \\
\hline & Total & 1162.086 & 639 & & & \\
\hline \multicolumn{7}{|c|}{ a. Dependent Variable: Culture } \\
\hline \multicolumn{7}{|c|}{ b. Predictors: (Constant), TDF, TDAS, TDP } \\
\hline
\end{tabular}

(Source: Primary Data)

The Analysis of Variance (ANOVA) allows researchers to test the null hypothesis statistically. The above table shows the result of ANOVA test, where the F ratio $=90.743$ and the P-value $<0.05$, this outcome indicates that there is less than $5 \%$ change that an $\mathrm{F}$ ratio of this value would be occur only coincidentally. Since the P-value is lesser than the significant level (0.05), the null hypothesis is rejected and alternative hypothesis is accepted signifying that Talent Development affects IT employees Organisational Culture.

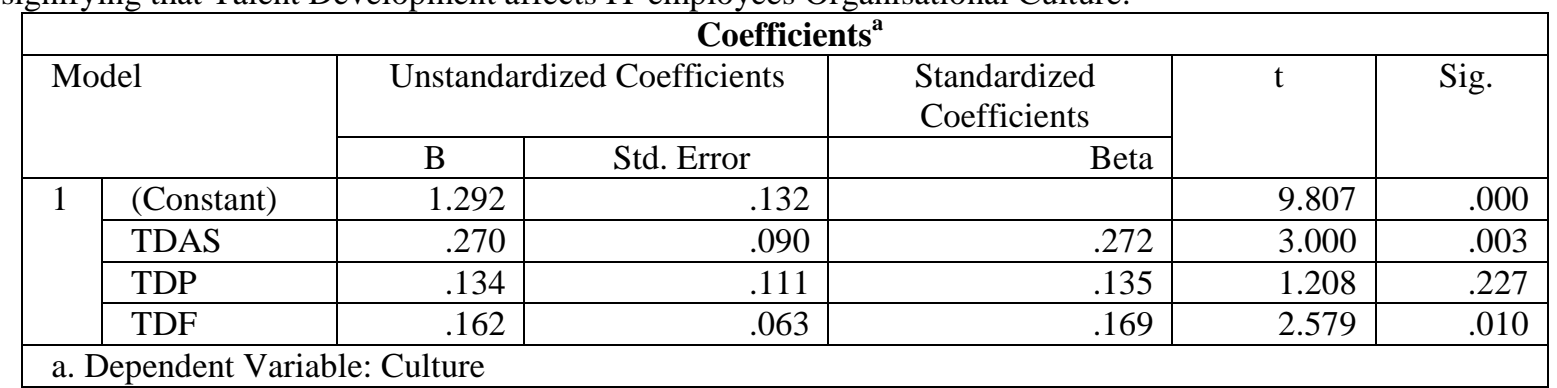

(Source: Primary Data) 
The result in the above coefficient table revealed that Talent Development affects IT employees Organisational Culture.

Table-9: Regression Model of Organisational Strategy and Talent Development among employees of select IT companies

\begin{tabular}{|l|c|c|c|c|}
\hline \multicolumn{5}{|c|}{ Model Summary } \\
\hline Model & R & R Square & Adjusted R Square & Std. Error of the Estimate \\
\hline 1 & $.546^{\mathrm{a}}$ & .298 & .295 & 1.12353 \\
\hline \multicolumn{2}{|l}{ a. Predictors: (Constant), TDF, TDAS, TDP } \\
\hline
\end{tabular}

(Source: Primary Data)

From the above table it is observed that the corelation coefficient $\mathrm{R}=.546$ it indicates the relation between Talent Development and Organisational Strategy Parameter of Innovation is constructive and both alter in the identical path. The coefficient of variance $\mathrm{R}^{2}$ shows that $29.8 \%$ of the deviation in the dependant factor (Organisational Strategy) is explained by the independent factor (Talent Development). The adjusted $\mathrm{R}^{2}$ mentioned in the above table shows the generalisability of the model. It enables generalising the result obtained from the select IT company employees to the universe. It is observed that the value of adjusted $\mathrm{R}^{2}=.295$ is close to the value of $\mathrm{R}^{2}=.298$. If the adjusted $\mathrm{R}^{2}$ is expelled from the $\mathrm{R}^{2}$ the value will be $(.298-.295=.003)$. This sum of decrease means that if the sample universe participates in the research and the model has been fitted then, there will be $0.3 \%$ less difference in the outcome.

\begin{tabular}{|c|c|c|c|c|c|c|}
\hline \multicolumn{7}{|c|}{ ANOVA $^{a}$} \\
\hline \multicolumn{2}{|c|}{ Model } & Sum of Squares & df & Mean Square & $\mathrm{F}$ & Sig. \\
\hline \multirow[t]{3}{*}{1} & Regression & 340.608 & 3 & 113.536 & 89.942 & $.000^{\mathrm{b}}$ \\
\hline & Residual & 802.842 & 636 & 1.262 & & \\
\hline & Total & 1143.450 & 639 & & & \\
\hline \multicolumn{7}{|c|}{ a. Dependent Variable: Strategy } \\
\hline \multicolumn{7}{|c|}{ b. Predictors: (Constant), TDF, TDAS, TDP } \\
\hline
\end{tabular}

(Source: Primary Data)

The Analysis of Variance (ANOVA) allows researchers to test the null hypothesis statistically. The above table shows the result of ANOVA test, where the $\mathrm{F}$ ratio $=89.942$ and the $\mathrm{P}$ - value $<0.05$, this outcome indicates that there is less than $5 \%$ change that an $\mathrm{F}$ ratio of this value would be occur only coincidentally. Since the P-value is lesser than the significant level (0.05), the null hypothesis is rejected and alternative hypothesis is accepted signifying that Talent Development affects IT employees Organisational Strategy.

\begin{tabular}{|c|c|c|c|c|c|c|}
\hline \multicolumn{7}{|c|}{ Coefficients $^{\mathrm{a}}$} \\
\hline \multirow{2}{*}{\multicolumn{2}{|c|}{ Model }} & \multicolumn{2}{|c|}{ Unstandardized Coefficients } & \multirow{2}{*}{$\begin{array}{c}\begin{array}{c}\text { Standardized } \\
\text { Coefficients }\end{array} \\
\text { Beta }\end{array}$} & \multirow[t]{2}{*}{$\mathrm{t}$} & \multirow[t]{2}{*}{ Sig. } \\
\hline & & $\mathrm{B}$ & Std. Error & & & \\
\hline \multirow[t]{4}{*}{1} & (Constant) & 1.318 & .131 & & 10.074 & .000 \\
\hline & TDAS & .185 & .089 & .188 & 2.072 & .039 \\
\hline & TDP & .201 & .110 & .204 & 1.825 & .069 \\
\hline & TDF & .172 & .062 & .181 & 2.757 & .006 \\
\hline
\end{tabular}

a. Dependent Variable: Strategy

(Source: Primary Data)

The result in the above coefficient table revealed that Talent Development affects IT employees Organisational Strategy.

Table-10: Regression Model of Organisational Resources and Talent Development among employees of select IT companies

\begin{tabular}{|l|c|c|c|c|}
\hline \multicolumn{5}{|c|}{ Model Summary } \\
\hline Model & R & R Square & Adjusted R Square & Std. Error of the Estimate \\
\hline 1 & $.537^{\mathrm{a}}$ & .288 & .285 & 1.14582 \\
\hline a. Predictors: (Constant), TDF, TDAS, TDP
\end{tabular}

(Source: Primary Data)

From the above table it is observed that the corelation coefficient $\mathrm{R}=.537$ it indicates the relation between Talent Development and Organisational Resources Parameter of Innovation is constructive and both alter in the identical path. The coefficient of variance $\mathrm{R}^{2}$ shows that $28.8 \%$ of the deviation in the dependant factor 
(Organisational Resources) is explained by the independent factor (Talent Development). The adjusted $\mathrm{R}^{2}$ mentioned in the above table shows the generalisability of the model. It enables generalising the result obtained from the select IT company employees to the universe. It is observed that the value of adjusted $\mathrm{R}^{2}=.285$ is close to the value of $\mathrm{R}^{2}=.288$. If the adjusted $\mathrm{R}^{2}$ is expelled from the $\mathrm{R}^{2}$ the value will be $(.288-.285=.003)$. This sum of decrease means that if the sample universe participates in the research and the model has been fitted then, there will be $0.3 \%$ less difference in the outcome.

\begin{tabular}{|c|c|c|c|c|c|c|}
\hline \multicolumn{7}{|c|}{ ANOVA $^{\mathbf{a}}$} \\
\hline \multicolumn{2}{|c|}{ Model } & Sum of Squares & df & Mean Square & $\mathrm{F}$ & Sig. \\
\hline \multirow[t]{3}{*}{1} & Regression & 338.377 & 3 & 112.792 & 85.911 & $.000^{\mathrm{b}}$ \\
\hline & Residual & 835.005 & 636 & 1.313 & & \\
\hline & Total & 1173.382 & 639 & & & \\
\hline \multicolumn{7}{|c|}{ a. Dependent Variable: Resources } \\
\hline \multicolumn{7}{|c|}{ b. Predictors: (Constant), TDF, TDAS, TDP } \\
\hline
\end{tabular}

(Source: Primary Data)

The Analysis of Variance (ANOVA) allows researchers to test the null hypothesis statistically. The above table shows the result of ANOVA test, where the F ratio $=85.911$ and the $\mathrm{P}$ - value $<0.05$, this outcome indicates that there is less than $5 \%$ change that an F ratio of this value would be occur only coincidentally. Since the P-value is lesser than the significant level (0.05), the null hypothesis is rejected and alternative hypothesis is accepted signifying that Talent Development affects IT employees Organisational Resources.

\begin{tabular}{|c|c|c|c|c|c|c|}
\hline \multicolumn{7}{|c|}{ Coefficients $^{\mathbf{a}}$} \\
\hline \multirow{2}{*}{\multicolumn{2}{|c|}{ Model }} & \multicolumn{2}{|c|}{ Unstandardized Coefficients } & \multirow{2}{*}{$\begin{array}{c}\begin{array}{c}\text { Standardized } \\
\text { Coefficients }\end{array} \\
\text { Beta } \\
\end{array}$} & \multirow[t]{2}{*}{$\mathrm{t}$} & \multirow[t]{2}{*}{ Sig. } \\
\hline & & B & Std. Error & & & \\
\hline \multirow[t]{4}{*}{1} & (Constant) & 1.338 & .133 & & 10.026 & .000 \\
\hline & TDAS & .140 & .091 & .140 & 1.531 & .126 \\
\hline & TDP & .271 & .113 & .271 & 2.407 & .016 \\
\hline & TDF & .143 & .064 & .149 & 2.259 & .024 \\
\hline
\end{tabular}

(Source: Primary Data)

The result in the above coefficient table revealed that Talent Development affects IT employees Organisational Resources.

\section{FINDINGS}

Among IT sector employee's talent development practices are explaining $26.4 \%$ deviation in employee individual personality. From the ANOVA table it is observed that administration support of talent development is significantly impacting employee individual personality.

Among IT sector employee's talent development practices are explaining $23.8 \%$ deviation in employee motivation. From the ANOVA table it is observed that feedback mechanism of talent development is significantly impacting employee motivation towards innovation.

Among IT sector employee's talent development practices are explaining $28.1 \%$ deviation in group climate. From the ANOVA table it is observed that feedback mechanism of talent development is significantly impacting group climate.

> Among IT sector employee's talent development practices are explaining $26.1 \%$ deviation in group leadership. From the ANOVA table it is observed that administration support of talent development is significantly impacting group leadership.

$>$ Among IT sector employee's talent development practices are explaining $28.8 \%$ deviation in Organisational resources. From the ANOVA table it is observed that practices of talent development are significantly impacting organisational resources.

\section{SUGGESTIONS}

$\checkmark$ Administration support of talent development is significantly impacting employee individual personality. The reason could be that for employee there is a need for achievement because manager complies with employees who perform well. Therefore, manager should give this indirect message that you need to perform well if he wants manager to comply with him. 
$\checkmark$ Feedback mechanism of talent management is significantly impacting motivation. The feedback mechanism will help employee in self-assessment that helps in building intrinsic motivation. Intrinsic motivation is a prime factor in innovation; therefore, to ensure intrinsic motivation as well as innovation feedback place a vital role.

$\checkmark$ The innovation is very new idea generated; so, it has high risk involved. This risk makes the job challenging, if the manager encourages these challenging jobs, then only employees will come-up with risk in the form of innovation.

$\checkmark$ From the research it is found that participative leadership is important. But participative leadership is not inherent quality of all the leaders. Therefore, management should conduct training programs to ensure participative leadership among all the leaders.

$\checkmark$ All the employees in the organisation are not equally skilled in all the functional areas. Therefore, the management should create an environment where employee ready to exchange their skills and knowledge among them-self. This environment not only increases the organisations overall expertise but also ensures sense of belongingness among the employees.

\section{CONCLUSION}

The current research is conducted to study the factors of talent development and innovation in the information technology organisations. The research is also conducted to examine the talent development factors impact on innovation in select IT companies in Mindspace IT Park, Hyderabad. For the talent development; management support, talent development practices and feedback factors are considered for the study. For innovation; Individual, group and organisational level factors are considered for the study. From the study it is found that talent development factors have significant impact on innovation factors. Therefore, the organisations wishing successful innovations have to consider employee talent development for effective results.

\section{REFERENCES}

1. A.A.R. Veenendaal, Enhancing innovation at work through human resource management, Ph.D. dissertation, Twente Uni., 2015.

2. A.R. Ma'atoofi, K. Tajeddini, The effect of entrepreneurship orientation on learning orientation and innovation: a study of small-sized business firms in Iran, International Journal of Trade, Economics and Finance. 1(3) (2010) 254-260.

3. Baker W E, Sinkula J M 2005 Environmental marketing strategy and firm performance: effect on new product performance and market share J. Acad. Market. Sci. 33 4 461-475.

4. Bersin, J. (2010), High-Impact Talent Management: Trends, Best Practices and Industry Solutions, Bersin, Los Angeles, $C A$.

5. Christensen, C.M., Johnson, C.W. and Horn, M.B. (2010), Disrupting Class, Expanded Edition: How Disruptive Innovation Will Change the Way the World Learns, McGraw Hill, New York, NY.

6. CIPD (2011), Learning and Talent Development, CIPD, London.

7. Ernst \& Young (2010), Managing Todays Global Workforce: Evaluating Talent Management to Improve Business, Ernst and Young, London.

8. J. Lee, M. Abu Ali, Innovative product advanced service systems (I-PASS): methodology, tools, and applications for dominant, Int. J. Adv. Manuf. Technol. 52(9-12) (2010) 1161-1173.

9. J. Rhee, T. Park, D.H. Lee, Drivers of innovativeness and performance for innovative SMEs in South Korea: mediation of learning orientation, Technovation. 30(1) (2009) 65-75.

10. J.H. Collins, J. Moschler, The life cycle of innovations, Defense AR Journal. 15(1) (2008) $75-85$.

11. Jaworski B J, Kohli, A K 1993 Market orientation: antecedents and consequences J. Market. $57353-70$.

12. Jori Hamilton (12/01/2021). How Talent Development Makes a Positive Impact on Your Business. Talentculture.

13. Juan A. Marin-Garcia, Lourdes Aznar-Mas, Fernando González Ladrón de Guevara. Innovation Types and Talent Management for Innovation. Working Papers on Operations Management Vol 2, $N^{o} 2$ (25-31)

14. Kuratko D F, Hornsby J S, Hayton J 2015 Corporate entrepreneurship: the innovative challenge for a new global economic reality Small Bus. Econ. 452 245-253.

15. M.F. Nosh Abadi, S.M. Khadem, A. Sadeghnia, Talent management and maintaining talented human resource: a case study in Kashan University of Medical Sciences, European Online Journal of Natural and Social Sciences. 2(3) (2013) 3446-3457.

16. Osaka, Japan; President, Representative Director, Gyo Sagara (2021). Ono Starts Innovation Talent Development Program. Ono Pharmaceutical Co., Ltd.

17. Reilly, P. (2008), "Identifying the right course for talent management", Public Personnel Management, Vol. 37 No. 4, pp. 381-8.

18. Sumita Datta, Pawan Budhwar, Upasna A. Agarwal \& Shivganesh Bhargava (2021): Impact of HRM practices on innovative behaviour: mediating role of talent development climate in Indian firms, The International Journal of Human Resource Management, DOI: 10.1080/09585192.2021.1973063

19. T.M. Amabile, How to kill creativity, Harv. Bus. Rev. 6(5) (1998) 77-87.

20. Urbancova H 2012 Competitive advantage achievement through innovation and knowledge J. Comp. 51 82-96. 